\title{
Effect of Ms Temperature on Strength and Toughness in Martensitic Fe-Ni-C Alloys*
}

\author{
By Minoru TANAKA, ,* Chong Sool CHOI, ${ }^{* * *}$ and Yoshihiko KOJIMA ${ }^{* *}$
}

\section{Synopsis}

The effect of Ms temperature on the ductility of martensite has been sludied by using $\mathrm{Fc}-\mathrm{Ni}-\mathrm{C}$ alloys with two levels of $\mathrm{Ms}$ temperatures, approximately $350^{\circ}$ and $-25^{\circ} \mathrm{C}$. The carbon content ranges from 0.14 to $0.33 w t^{\%}$, while nickel content is varied to adjust the Ms temperature. Tensile test and Charpy impact test are used to evaluate the ductility of martensite.

The martensite with $\mathrm{Ms}$ of $350^{\circ} \mathrm{C}$ shows a much better combination of a high strength and ductility than the martensite with $M$ s of $-25^{\circ} \mathrm{C}$. As an example, it may be noted that the $0.33 \% \mathrm{C}$ alloy with $\mathrm{Ms}$ of $350^{\circ} \mathrm{C}$ has a value of $14 \%$ in elongation, $54 \%$ in reduction of area and $4.0 \mathrm{~kg}-\mathrm{m}$ in Charpy shelf energy at a yield strength level of $160 \mathrm{~kg} / \mathrm{mm}^{2}$ when tempered at $140^{\circ} \mathrm{C}$.

It is observed that the preferable combination of a high strength and a good toughness in the alloys subjected to the higher level of Ms temperature, $356^{\circ} \mathrm{C}$ may be attributed to the fine and uniform carbide distribution, the dislocation substructure (lath martensite), deformation by slip and the absence of retained austenite.

\section{Introduction}

A number of studies have been recently made on the strength, ${ }^{1-4)}$ hardness, ${ }^{5)}$ and deformation mode ${ }^{6-8)}$ in $\mathrm{Fe}-\mathrm{Ni}-\mathrm{C}$ martensitic alloys having a wide range of Ms temperatures from $-30^{\circ}$ to $350^{\circ} \mathrm{C}$. For example, Winchell and Cohen ${ }^{1)}$ investigated the yield strength of $\mathrm{Fe}-\mathrm{Ni}-\mathrm{C}$ alloys with $\mathrm{Ms}$ of approximately $-30^{\circ} \mathrm{C}$ and suggested that the yield strength has a cube-root dependence on carbon content. Roberts and Owen ${ }^{2)}$ and Chilton and Kelly $^{3)}$ suggested a square-root dependence on carbon content, while Leslie and Sober $^{9}$ ) suggested a simple linear dependence. On the other hand, Tanaka and $\mathrm{Choi}^{5}$ investigated the hardness of $\mathrm{Fe}-\mathrm{Ni}-\mathrm{C}$ martensites having three levels of $\mathrm{Ms}$ temperatures, $350^{\circ}, 220^{\circ}$, and $-25^{\circ} \mathrm{C}$, and reported that the hardness of martensites becomes higher in accordance with increasing Ms temperature because of the precipitation hardening due to carbide in the martensites of a higher Ms temperature. It has been suggested that the dependence of yield strength of ferrous martensites on carbon content is closely related to $\mathrm{Ms}$ temperature.

Richman, ${ }^{6)}$ Magee et al., ${ }^{8)}$ and Tamura et al. ${ }^{7)}$ investigated the deformation mode of $\mathrm{Fe}-\mathrm{Ni}-\mathrm{C}$ martensitic alloys having Ms of subzero-temperature, and reported that the martensites are deformed by wavy slip at relatively lower levels of carbon content, while at higher levels of carbon content the deformation of the martensites is accompanied by mechanical twinning.

However, there is few investigations of tensile and impact properties for these $\mathrm{Fe}-\mathrm{Ni}-\mathrm{C}$ martensitic alloys having Ms of subzero-temperatures. Furthermore, there has been done no comparison of the impact toughness values of the martensite with Ms of subzero-temperature and the martensite with a higher level of Ms temperature. The former is a virgin martensite having partially internal twins, and the latter is an autotempered martensite having a dislocation substructure.

In the present paper, $\mathrm{Fe}-\mathrm{Ni}-\mathrm{C}$ alloys ranging in carbon content from 0.14 to $0.33 \mathrm{wt}_{\mathrm{o}}$ were prepared to have two levels of Ms temperatures, approximately $-25^{\circ}$ and $350^{\circ} \mathrm{C}$, by adjusting the nickel content, and the tensile and impact toughness properties of these alloys were investigated.

\section{Experimental Procedures}

The alloys were prepared as ingots of $50 \mathrm{~kg}$ by melting in vacuum using pure iron, nickel, and carbon. The ingots were hot rolled to bars with a diameter of $100 \mathrm{~mm}$, and then hot forged to plates $15 \times 35 \mathrm{~mm}$ in cross section. These plates were annealed at $1200^{\circ} \mathrm{C}$ for $24 \mathrm{hr}$ using a suitable atmosphere to minimize decarburization. The chemical composition and Ms temperatures of alloys used in this study are listed in Table 1 . The outer oxidized and

Table 1. Chemical composition and Ms temperatures of alloys used

\begin{tabular}{|c|c|c|c|c|c|c|c|c|c|}
\hline Alloy No. & $\mathrm{C}$ & $\mathrm{Ni}$ & $\mathrm{Mn}$ & $\mathrm{Si}$ & $\mathrm{P}$ & $\mathrm{S}$ & $\mathrm{Al}$ & $\mathrm{N}$ & $\mathrm{Ms}\left({ }^{\circ} \mathrm{C}\right)$ \\
\hline 1 & 0.15 & 6.04 & 0.46 & 0.005 & 0.005 & $<0.002$ & 0.003 & 0.003 & 345 \\
\hline 2 & 0.23 & 4.38 & 0.49 & 0.004 & 0.003 & $<0.002$ & 0.003 & 0.003 & 350 \\
\hline 3 & 0.33 & 2.53 & 0.49 & 0.006 & 0.006 & $<0.002$ & 0.004 & 0.002 & 350 \\
\hline 4 & 0.14 & 27.00 & 0.48 & 0.005 & 0.005 & $<0.002$ & 0.004 & 0.002 & $-(22 \sim 26)$ \\
\hline 5 & 0.23 & 25.27 & 0.51 & 0.004 & 0.006 & $<0.002$ & 0.004 & 0.002 & $-(24 \sim 26)$ \\
\hline 6 & 0.33 & 23.60 & 0.50 & 0.004 & 0.006 & $<0.002$ & 0.004 & 0.001 & $-(28 \sim 30)$ \\
\hline
\end{tabular}

* $\quad$ Received September 22, 1973.

** Research Laboratory of Precision Machinery and Electronics, Tokyo Institute of Technology, Ōokayama, Meguro-ku, Tokyo 152.

*** Formerly Research Laboratory of Precision Machinery and Electronics, Tokyo Institute of Technology, now Department of Metallurgical Engineering, Inha Institute of Technology, Inchon, Korea. 


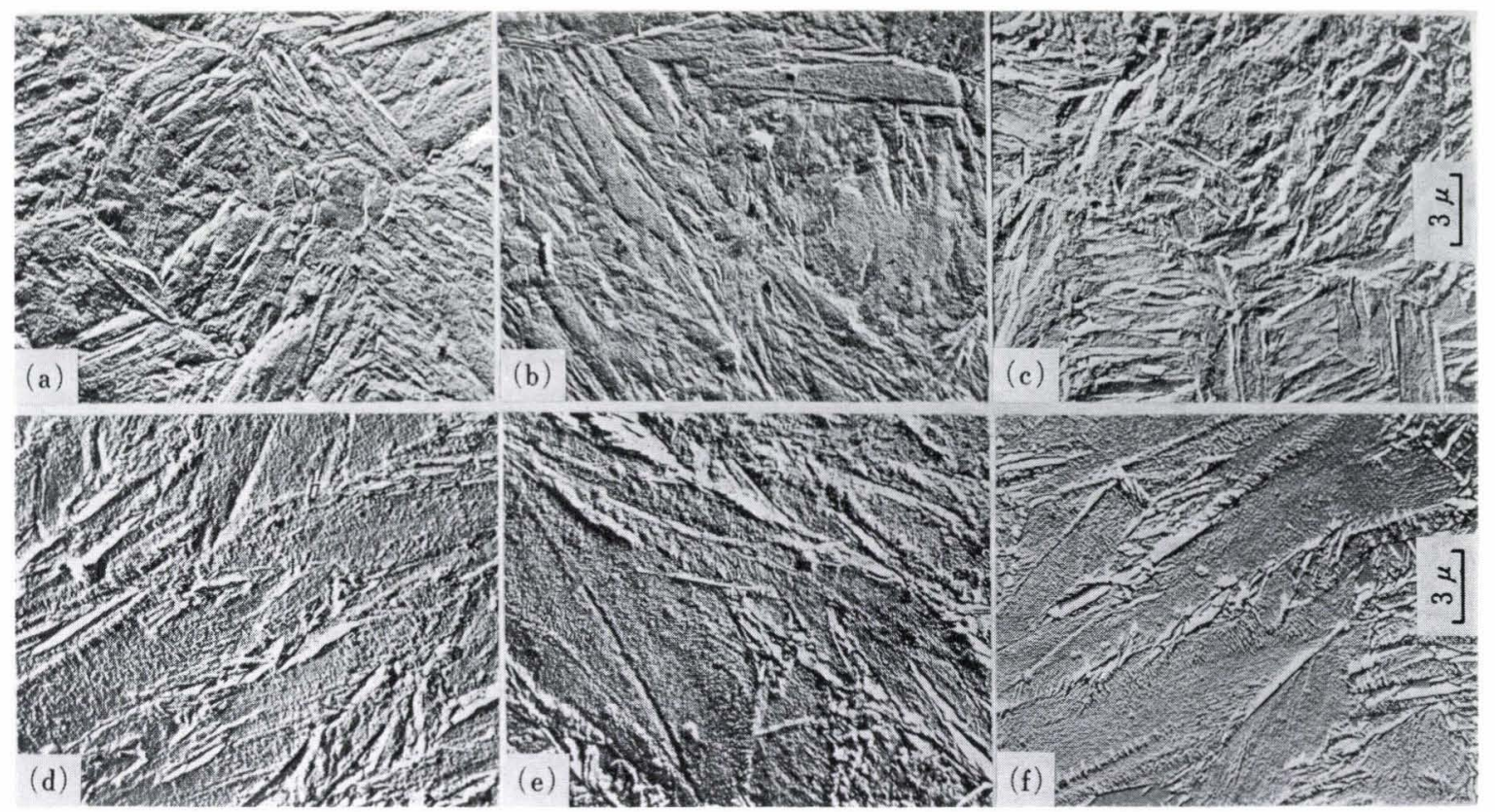

Photo. 1. Replica electron micrographs of as-quenched Fe-Ni-C martensites: (a) Alloy 1, (b) Alloy 2, (c) Alloy 3, (d) Alloy 4, (e) Alloy 5, (f) Alloy $6 \quad(\times 3 / 4)$

decarburized layers of the plates were machined off. The threaded round tensile specimens with a reduced gauge section of $18 \mathrm{~mm}$ length and $4 \mathrm{~mm}$ diam., and standard Charpy $2 \mathrm{~mm} \mathrm{~V}$-notch impact specimens having major axes parallel to the longitudinal direction of the plates were machined from the plates. All specimens were austenitized at $930^{\circ} \mathrm{C}$ for $20 \mathrm{~min}$ in a vacuum tube furnace, then quenched violently into iced brine. After quenching, the specimens were immediately transferred into a liquid nitrogen bath and stored there until needed. Tempering was performed in a water bath or in an oil bath. Tensile tests were performed on an Instron type testing machine at room temperature, at a nominal strain rate of $1 \times 10^{-3}$ $\mathrm{sec}^{-1}$. Impact Charpy tests were performed on a standard $30 \mathrm{~kg}-\mathrm{m}$ testing machine. The striker was instrumented with silicon semi-conductor strain gauges and an oscilloscope to record the load-time curve under impact conditions. ${ }^{10)}$ The plate specimens, $4 \times 8 \times$ $15 \mathrm{~mm}$, for X-ray diffraction and microscopic examination were heat-treated under the same conditions as the tensile and impact specimens. Austenite contents were determined by the $\mathrm{X}$-ray integrated intensity measurement using $\operatorname{CoK} \alpha$ radiation as described previously. ${ }^{5)}$

\section{Experimental Results and Discussion}

\section{Mechanical Properties of As-quenched Martensites with Ms of $-25^{\circ}$ and $350^{\circ} \mathrm{C}$}

The microstructures of the $\mathrm{Fe}-\mathrm{Ni}-\mathrm{C}$ alloys with $\mathrm{Ms}$ of $-25^{\circ} \mathrm{C}$ subjected to subzero-treatment at $-196^{\circ} \mathrm{C}$ in liquid nitrogen and the structures of the alloys with $\mathrm{Ms}$ of $350^{\circ} \mathrm{C}$ quenched into iced brine from $930^{\circ} \mathrm{C}$ are shown in Photo. 1. As shown in Photo. 1, the structures of the alloys with $\mathrm{Ms}$ of $-25^{\circ} \mathrm{C}$ are composed of martensite plates with midribs, whereas the
Table 2. Amounts of retained austenite after subzerotreatment (vol\%)

\begin{tabular}{c|c|c|c|c|c|}
\hline $\begin{array}{c}\text { Alloy } \\
\text { No. }\end{array}$ & \multicolumn{4}{|c}{ Temperatures in subzero-treatments $\left({ }^{\circ} \mathrm{C}\right)$} \\
\hline-55 & -75 & -90 & -130 & -196 \\
\hline 4 & 72 & 40 & 34 & 32 & 12 \\
\hline 5 & 81 & 63 & 50 & 27 & 16 \\
\hline 6 & 90 & 71 & 54 & 31 & 22 \\
\hline
\end{tabular}

alloys with $\mathrm{Ms}$ of $350^{\circ} \mathrm{C}$ have lath martensite structures. Regarding the alloys with the same Ms temperature, the structures are similar, independent of the levels of carbon content. By X-ray diffraction, it was confirmed that a complete transformation to $100 \%$ martensite was achieved in the alloys with $\mathrm{Ms}$ of $350^{\circ} \mathrm{C}$. However, the alloys with $\mathrm{Ms}$ of $-25^{\circ} \mathrm{C}$ were not completely transformed to $100 \%$ martensite even by cooling in liquid nitrogen $\left(-196^{\circ} \mathrm{C}\right)$, which contained retained austenite of 12,16 , and $22 \mathrm{vol} \%$ for the alloys with $0.14,0.23$, and $0.33 \% \mathrm{C}$, respectively.

Accordingly, various ratios of martensite-to-austenite were obtained for these alloys with $\mathrm{Ms}$ of $-25^{\circ} \mathrm{C}$ by adjusting the cooling temperature below Ms temperature. Table 2 shows the amounts of retained austenite which were measured successively in each stage of subzero-treatments. Then the mechanical properties of martensite-austenite aggregates were measured as a function of the volume percent of austenite. The data for the mechanical properties of the alloys were plotted against the austenite content in Fig. 1. As shown in Fig. 1, ultimate tensile strength (UTS) and yield strength $(0.2 \%$ off set) decrease linearly with the austenite content, and they run parallel to each other. The reduction of area increases linearly with the austenite content. The Charpy impact energy, total elongation and uniform elongation 


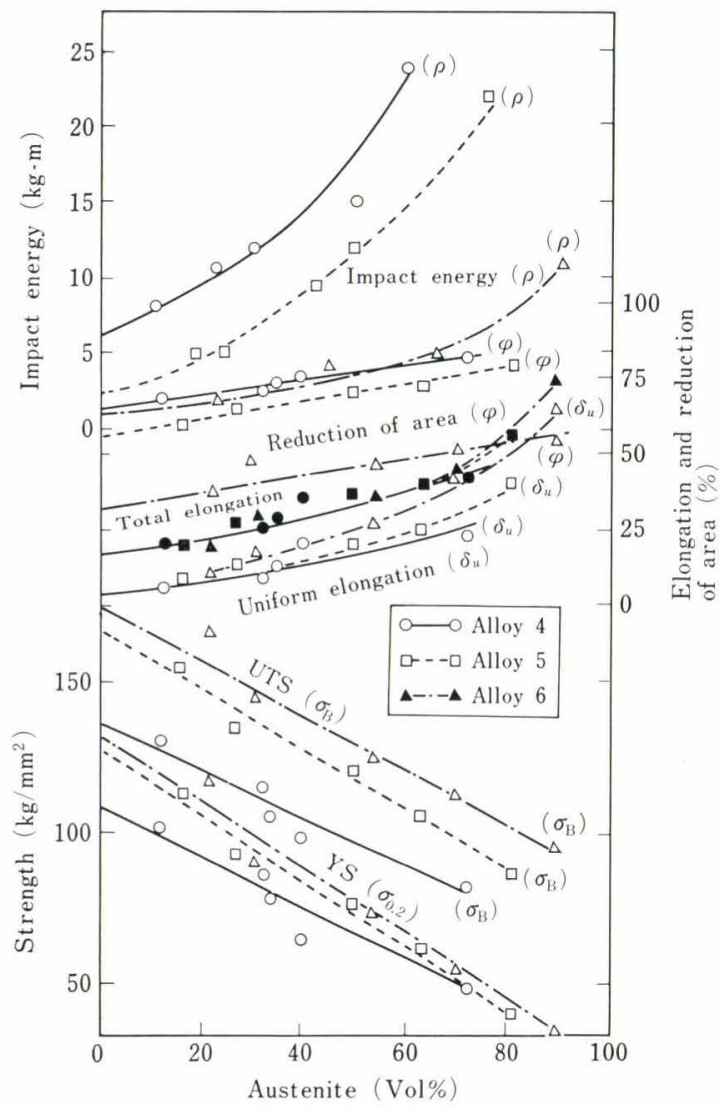

Fig. 1. Mechanical properties of the alloys with Ms of $-25^{\circ} \mathrm{C}$ as a function of retained austenite content. Solid marks indicate the total elongation.

increase as smooth curves with the austenite content. It can be seen that at the same austenite content the reduction of area and the Charpy impact energy increase with lowering the carbon content, whereas the elongation shows nearly an equal value at a fixed level of austenite content, irrespective of levels of carbon content. By extrapolating the elongation data to zero percent austenite in Fig. 1, a value of about $16 \%$ in elongation is obtained for $100 \%$ martensite of all the alloys. The ultimate tensile strength, yield strength, reduction of area, and Charpy impact energy for $100 \%$ martensite of each alloy were also obtained by extrapolating the corresponding data to zero percent austenite in Fig. 1.

Some mechanical properties of $100 \%$ martensites with $\mathrm{Ms}$ of $-25^{\circ}$ and $350^{\circ} \mathrm{C}$ are shown in Fig. 2 as a function of carbon content. As shown in Fig. 2, the ultimate tensile strength and yield strength of the martensites with $\mathrm{Ms}$ of $350^{\circ} \mathrm{C}$ are higher than those of the martensites with $\mathrm{Ms}$ of $-25^{\circ} \mathrm{C}$ at a fixed level of carbon content, as in the case of the results of hardness tests reported in the previous paper. ${ }^{5}$ It may be noted that the Charpy impact energy of the martensites with $\mathrm{Ms}$ of $350^{\circ} \mathrm{C}$ is higher than that of the martensites with $\mathrm{Ms}$ of $-25^{\circ} \mathrm{C}$ in spite of higher strength levels in the former. The difference in impact energy between the martensites with Ms of $-25^{\circ}$ and $350^{\circ} \mathrm{C}$ becomes greater with decreasing carbon content.

The impact energy and the reduction of area were

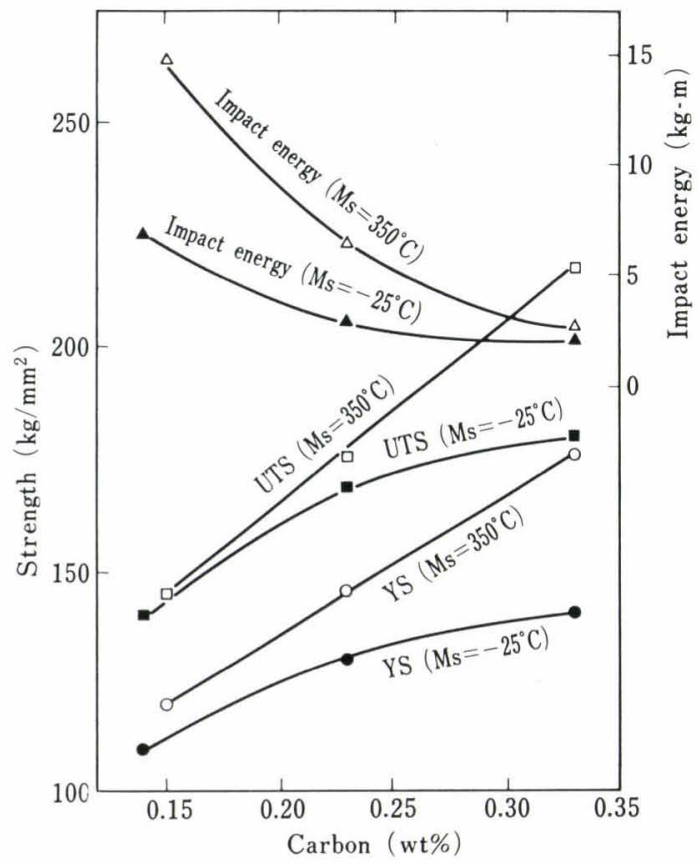

Fig. 2. Impact energy, yield strength (YS), and ultimate tensile strength (UTS) for 100\% martensitic structure of $\mathrm{Fe}-\mathrm{Ni}-\mathrm{C}$ alloys as a function of the $\mathrm{Ms}$ temperature and the carbon content

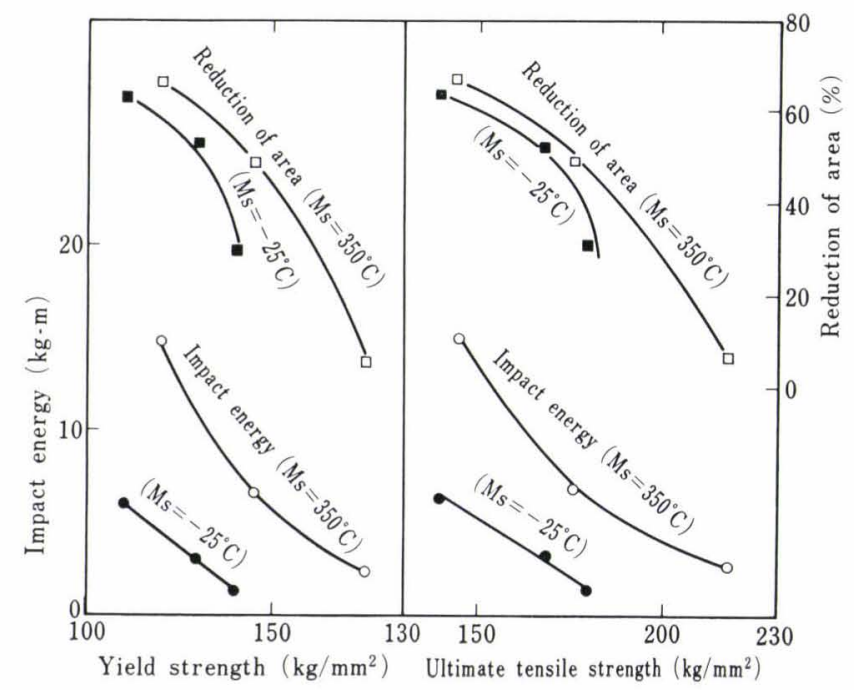

Fig. 3. Relationship between impact energy, reduction of area and strength of the $100 \%$ martensitic $\mathrm{Fe}-\mathrm{Ni}-\mathrm{C}$ alloys with $\mathrm{Ms}$ of $350^{\circ}$ and $-25^{\circ} \mathrm{C}$

plotted against the yield and ultimate tensile strengths for these martensites in Fig. 3. As shown in Fig. 3, at a strength level in as-quenched condition, the martensites with $\mathrm{Ms}$ of $350^{\circ} \mathrm{C}$ have a better toughness than the martensites with $\mathrm{Ms}$ of $-25^{\circ} \mathrm{C}$.

The relationship between the Charpy impact energy and the test temperature of the martensites with Ms of $-25^{\circ}$ and $350^{\circ} \mathrm{C}$ are shown in Fig. 4. The transition temperature of the martensites with $\mathrm{Ms}$ of $350^{\circ} \mathrm{C}$ is lowered as the carbon content decreases. This lowering transition temperature may be attributed to the increase in nickel content, in addition to the decrease in carbon content. However, the transition temperature of the martensites with $\mathrm{Ms}$ of $-25^{\circ} \mathrm{C}$ does not appear in a range of temperatures above $-196^{\circ} \mathrm{C}$. 
At a fixed level of carbon content, the room temperature impact energy of the martensites with Ms of $350^{\circ} \mathrm{C}$ is greater than, or as great as that of the martensites with $\mathrm{Ms}$ of $-25^{\circ} \mathrm{C}$, as shown in Fig. 4. The impact energy at $-196^{\circ} \mathrm{C}$ for all the martensites, however, becomes greater in accordance with the increased nickel content, irrespective of Ms temperature and of the carbon content.

It seems that the room temperature toughness of $\mathrm{Fe}-\mathrm{Ni}-\mathrm{C}$ martensites is probably attributed to the carbon content and structural factors such as a substructure (internal twins, dislocations) and precipitates of carbide, while the toughness of the $\mathrm{Fe}-\mathrm{Ni}-\mathrm{C}$ martensites at relatively lower subzero-temperatures may be mainly attributed to the nickel content. The loadtime curves in impact test of the martensites with $\mathrm{Ms}$

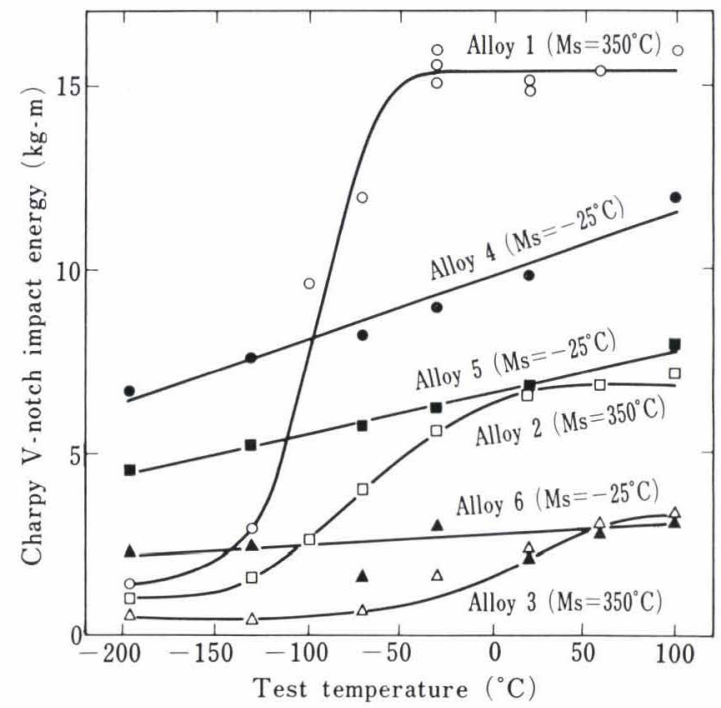

Fig. 4. Charpy $\mathrm{V}$-notch impact test transition temperature curves for the martensitic $\mathrm{Fe}-\mathrm{Ni}-\mathrm{C}$ alloys as quenched state
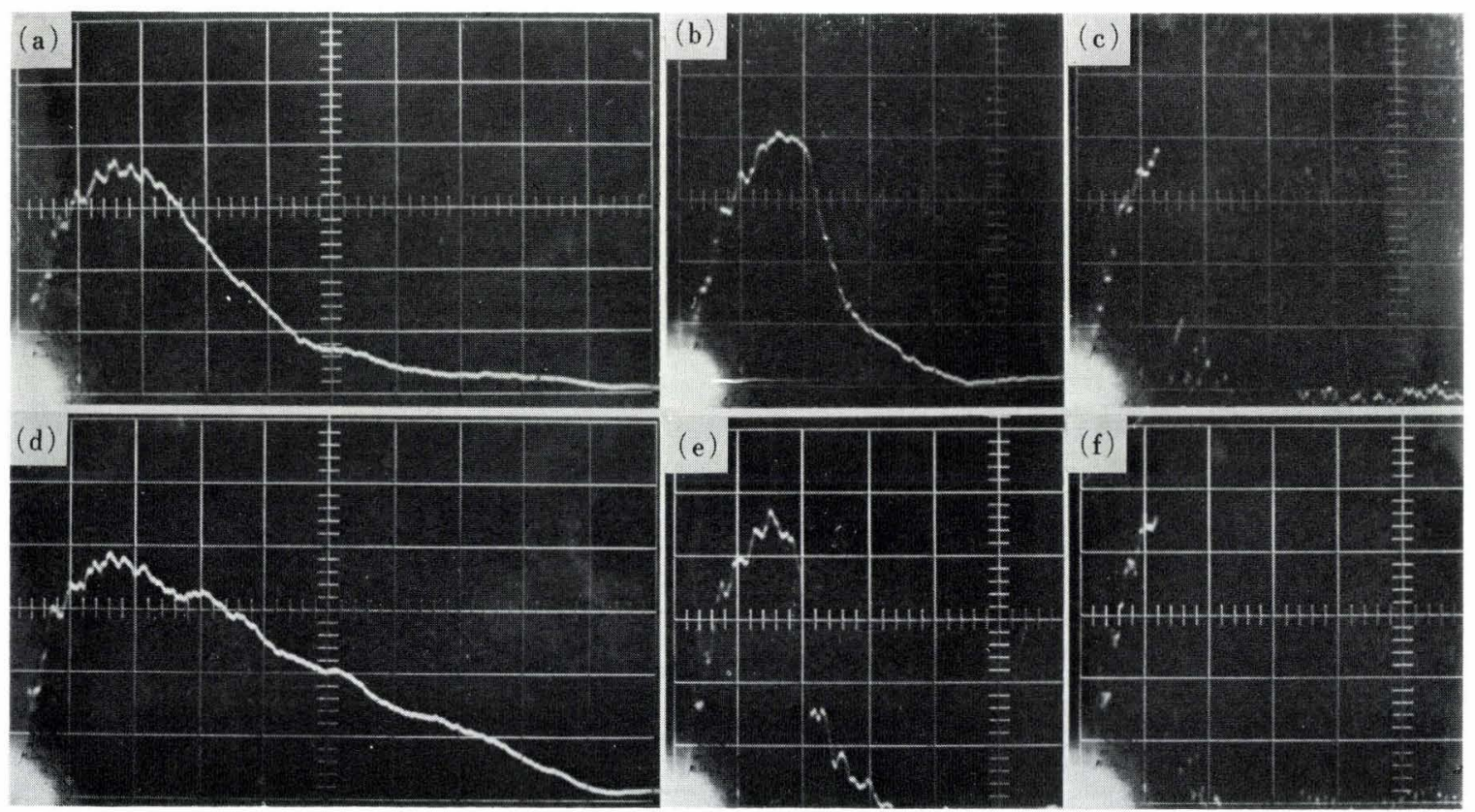

of $-25^{\circ}$ and $350^{\circ} \mathrm{C}$ are shown in Photo. 2. If it is assumed that the crack is initiated at the maximum load in those load-time curves, then the area under the curve to the left of the peak corresponds to the crack initiation energy and the area to the right of the peak corresponds to the crack propagation energy. The crack initiation and propagation energies, therefore, can be estimated from the ratio of both areas, using the measured absorbed energy for breaking. The crack initiation energy estimated in this way is about $3 \mathrm{~kg}-\mathrm{m}$ for all the martensites with $\mathrm{Ms}$ of $350^{\circ}$ and $-25^{\circ} \mathrm{C}$. Accordingly, it may be seen that the difference of impact energy in $\mathrm{Fe}-\mathrm{Ni}-\mathrm{C}$ martensites having a wide range of $\mathrm{Ms}$ temperatures from $-25^{\circ}$ to $350^{\circ} \mathrm{C}$ is mainly controlled by crack propagation energy. Photograph 2 also shows that when the carbon content of the alloys becomes higher, the crack propagation energy decreases clearly, irrespective of the levels of Ms temperature.

\section{Mechanical Properties of Tempered Martensites with Ms of $-25^{\circ}$ and $350^{\circ} \mathrm{C}$}

All the martensites with $\mathrm{Ms}$ of $-25^{\circ}$ and $350^{\circ} \mathrm{C}$ were tempered for one hour at various temperatures between $40^{\circ}$ and $450^{\circ} \mathrm{C}$. The martensites with the same Ms temperature showed similar tempering behavior, irrespective of the levels of carbon content. The mechanical properties of the martensites with $\mathrm{Ms}$ of $-25^{\circ}$ and $350^{\circ} \mathrm{C}$ are typified by those of the alloys with $0.23 \% \mathrm{C}$ (alloys 5 and 2). For example, in the alloy $5\left(\mathrm{Ms}=-25^{\circ} \mathrm{C}\right)$ during the tempering up to $450^{\circ} \mathrm{C}$, ultimate tensile strength decreased from 150 to $87 \mathrm{~kg} / \mathrm{mm}^{2}$ with increasing the elongation from 18 to $26 \%$ and the reduction of area from 64 to $66 \%$. The impact energy showed a minimum around $40^{\circ} \mathrm{C}$, coinciding with a peak in hardness at the same tempering temperature, and also the reduction of area

Photo. 2. Load-time curves and absorbed energies for breaking at room temperature in Charpy impact test for the as-quenched alloys with $\mathrm{Ms}$ of $-25^{\circ}$ and $350^{\circ} \mathrm{C}$ : (a) Alloy 4 (9.5 kg-m), (b) Alloy 5 (5.6 kg-m), (c) Alloy 6 (2.7 kg-m), (d) Alloy 1 (14.8 kg-m), (e) Alloy 2 (6.3 kg-m), (f) Alloy $3(2.8 \mathrm{~kg}-\mathrm{m}) \quad(\times 5 / 6)$ 
decreased slightly to $63 \%$. Similarly, the hardening at tempering at $40^{\circ} \mathrm{C}$ was also observed in the alloys 4 and 6 with $\mathrm{Ms}$ of $-25^{\circ} \mathrm{C}$. When the alloy $2(\mathrm{Ms}=$ $350^{\circ} \mathrm{C}$ ) was tempered up to $450^{\circ} \mathrm{C}$, the ultimate tensile strength decreased from 175 to $86 \mathrm{~kg} / \mathrm{mm}^{2}$ with increasing the elongation from 13 to $24 \%$ and the reduction of area from 50 to $75 \%$. At tempering up to $100^{\circ} \mathrm{C}$, the strength, hardness, impact energy, reduction of area and elongation remained almost constant, and then on increasing the tempering temperature above $100^{\circ} \mathrm{C}$ the reduction of area increased rapidly to $62 \%$. On increasing the temperature further above $120^{\circ} \mathrm{C}$, the impact energy, elongation, and reduction of area increased progressively with decreasing the strength and hardness. Such improvement of the reduction of area around $120^{\circ} \mathrm{C}$ was not observed clearly in the alloy 1 with lower carbon content, but became remarkable in the alloy 3 with higher carbon content. The reduction of area of the alloy 3 increased from 6 to $50 \%$ after the tempering at $120^{\circ} \mathrm{C}$.

As revealed by these results, although the alloys with $\mathrm{Ms}$ of $350^{\circ} \mathrm{C}$ having higher levels of strength in the as-quenched state showed lower levels of elongation and reduction of area than the martensites with Ms of $-25^{\circ} \mathrm{C}$, the ductility of the former was significantly improved by tempering at $120^{\circ}$ to $150^{\circ} \mathrm{C}$.

In order to compare the ductility and toughness of both tempered martensites with $\mathrm{Ms}$ of $-25^{\circ} \mathrm{C}$ and $350^{\circ} \mathrm{C}$ at the same strength levels, the elongation, reduction of area and impact energy were plotted against the ultimate tensile strength in Figs. 5, 6, and 7. As shown in Fig. 5, there is no substantial difference in elongation between the martensites with Ms of $-25^{\circ}$ and $350^{\circ} \mathrm{C}$. It can be seen, however, that the relationship between elongation and strength of all the $\mathrm{Fe}-\mathrm{Ni}-\mathrm{C}$ martensites with $\mathrm{Ms}$ of $-25^{\circ}$ and $350^{\circ} \mathrm{C}$ is separated into three regions. The first region is one in which the elongation increases with decreasing the strength level below $100 \mathrm{~kg} / \mathrm{mm}^{2}$, the second is a region in which the elongation remains almost constant at strength levels between 100 and $200 \mathrm{~kg} / \mathrm{mm}^{2}$ and the third is a region in which the elongation decreases rapidly with increasing strength level above 200

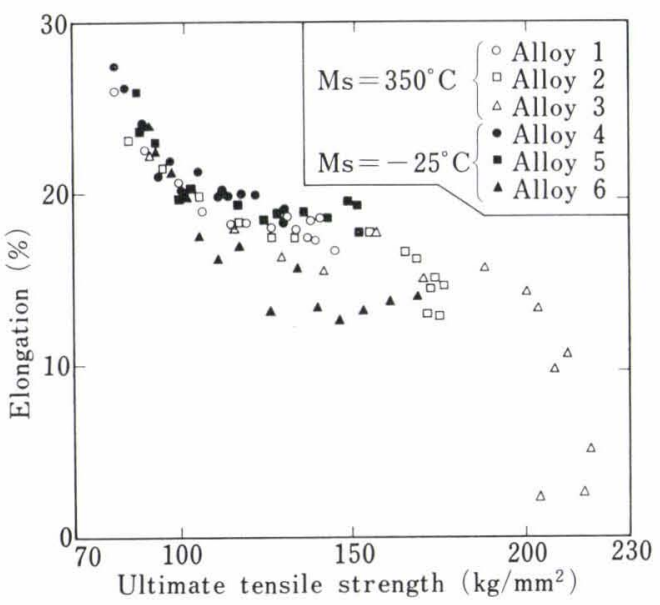

Fig. 5. Relationship between ultimate tensile strength and elongation for the tempered martensitic $\mathrm{Fe}-\mathrm{Ni}-\mathrm{C}$ alloys with $\mathrm{Ms}$ of $350^{\circ} \mathrm{C}$ and $-25^{\circ} \mathrm{C}$ $\mathrm{kg} / \mathrm{mm}^{2}$. However, as shown in Fig. 6, the reduction of area of the martensites with $\mathrm{Ms}$ of $350^{\circ} \mathrm{C}$ is greater than that of the martensites with $\mathrm{Ms}$ of $-25^{\circ} \mathrm{C}$ at a fixed strength level for the alloys with the same carbon content. From Fig. 6, it may be seen that the reduction-of-area values of all the $\mathrm{Fe}-\mathrm{Ni}-\mathrm{C}$ martensites with $\mathrm{Ms}$ of $-25^{\circ}$ and $350^{\circ} \mathrm{C}$ scatter from 50 to $80 \%$ at strength levels between 70 and $180 \mathrm{~kg} / \mathrm{mm}^{2}$, and decrease rapidly with increasing strength level above $180 \mathrm{~kg} / \mathrm{mm}^{2}$ as in the case of elongation. It may be suggested, from Figs. 5 and 6, that strength of $\mathrm{Fe}-\mathrm{Ni}-\mathrm{C}$ martensite can be varied from approximately 100 to $200 \mathrm{~kg} / \mathrm{mm}^{2}$ without much loss in ductility by controlling structural factors.

As shown in Fig. 7, in the alloys with the same level of carbon content, the impact toughness of the mar-

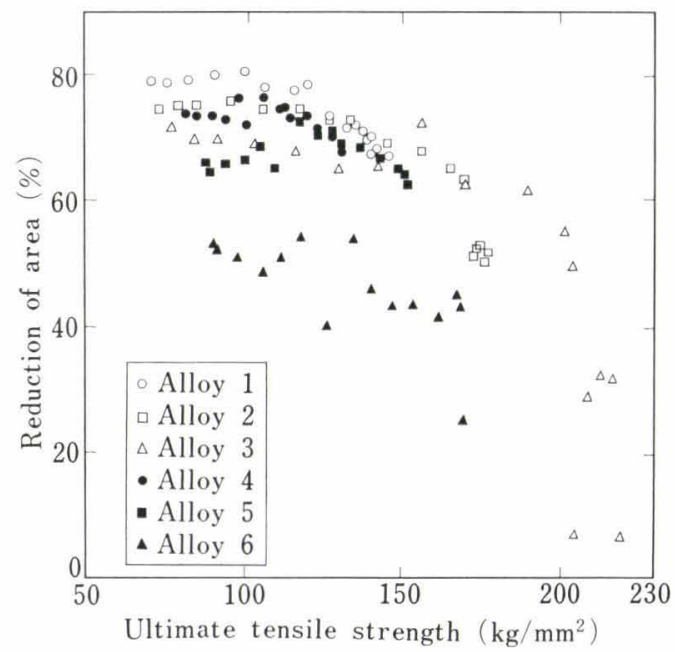

Fig. 6. Relationship between ultimate tensile strength and reduction of area for the tempered martensitic $\mathrm{Fe}-\mathrm{Ni}-\mathrm{C}$ alloys with $\mathrm{Ms}$ of $350^{\circ}$ and $-25^{\circ} \mathrm{C}$

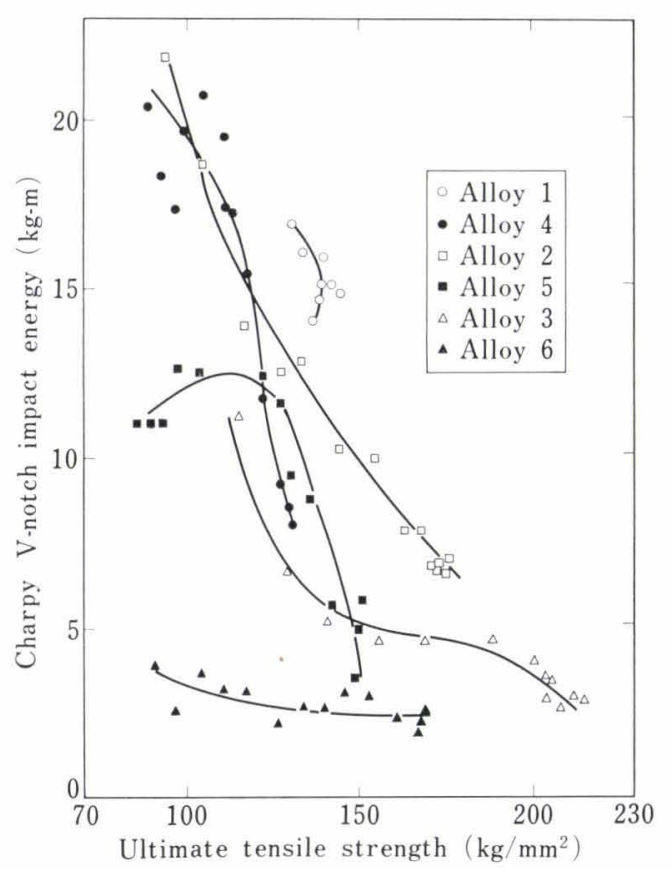

Fig. 7. Relationship between ultimate tensile strength and impact energy for the tempered martensitic $\mathrm{Fe}-\mathrm{Ni}-$ $\mathrm{C}$ alloys with $\mathrm{Ms}$ of $350^{\circ}$ and $-25^{\circ} \mathrm{C}$ 
tensites with $\mathrm{Ms}$ of $350^{\circ} \mathrm{C}$ is much superior compared to that of the martensities with $\mathrm{Ms}$ of $-25^{\circ} \mathrm{C}$ at a fixed strength level, and at a fixed toughness level the strength of martensites with $\mathrm{Ms}$ of $350^{\circ} \mathrm{C}$ is higher than that of the martensites with $\mathrm{Ms}$ of $-25^{\circ} \mathrm{C}$.

Photograph 3 is an electron micrograph of the alloy $6\left(\mathrm{Ms}=-25^{\circ} \mathrm{C}\right)$ quenched from $930^{\circ} \mathrm{C}$. It can be seen that the martensite of the alloy 6 contains many internal twins. On the other hand, the martensite of the alloy $3\left(\mathrm{Ms}=350^{\circ} \mathrm{C}\right)$ is a lath type with dispersed very small carbide particles as shown in Photo. 4(a) and (b). These transmission electron microphotographs were taken using $200 \mathrm{kV}$ JEM microscope by courtesy of Prof. Nagakura and Mr. Hirotsu of Tokyo Institute of Technology.

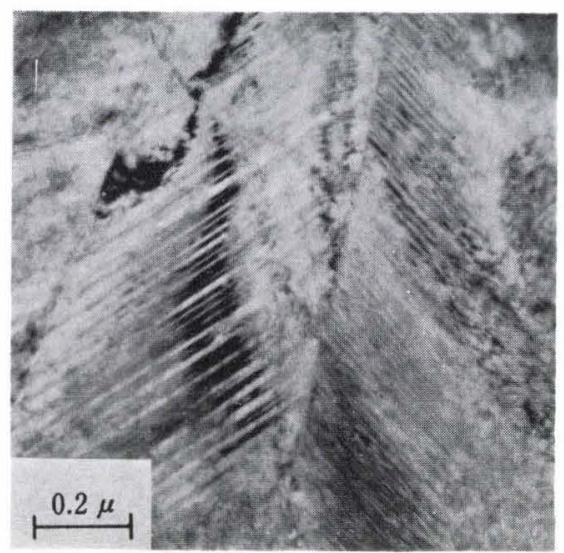

Photo. 3. Transmission electron micrograph of the alloy 6 $\left(0.33 \% \mathrm{C}\right.$, Ms: $\left.-25^{\circ} \mathrm{C}\right)$ as quenched state
Photograph 5(a) and (b) also shows the typical microstructures of the alloys 3 and 6 respectively after compression tests. The mechanical twins are revealed clearly in the alloy 6 , but are not observed in the alloy 3. The alloy 3 deformed with wavy slips. These different modes of deformation between the martensites with $\mathrm{Ms}$ of $-25^{\circ}$ and $350^{\circ} \mathrm{C}$ may be pointed out as one of the important factors to show the difference of toughness. In the martensites with Ms of $350^{\circ} \mathrm{C}$, carbide particles are expected to be distributed uniformly and finely, because in the case of lath martensites with a higher Ms temperature, dislocations may become nucleation sites for carbide precipitation during quenching and tempering. ${ }^{11)}$ On the other hand, in the case of partially twinned martensites, twin boundaries may give rise to a non-uniform carbide distribution. ${ }^{12)}$ Furthermore, it may be expected that in the case of martensites with $\mathrm{Ms}$ of $350^{\circ} \mathrm{C}$, the matrix will be easily deformed due to tempering at higher temperature, and carbide particles become so large that dislocations cannot cut the precipitates and thus wavy slip will occur easily. As a result, it seems that the superior toughness of the martensites with $\mathrm{Ms}$ of $350^{\circ} \mathrm{C}$ may be mainly attributed to the fine and uniform carbide distribution, absence of twin, and, further, the deformation mode of wavy slips.

Of all the alloys investigated in this study, the $0.33 \% \mathrm{C}$ alloy with $\mathrm{Ms}$ of $350^{\circ} \mathrm{C}$ (alloy 3 ) showed the best combination of high strength and ductility when tempered at $140^{\circ} \mathrm{C}$ and $160^{\circ} \mathrm{C}$. Some stress-strain curves of the alloys tempered at $140^{\circ} \mathrm{C}$ are shown in Fig. 8. The alloy 3 shows $14.5 \%$ in elongation at a
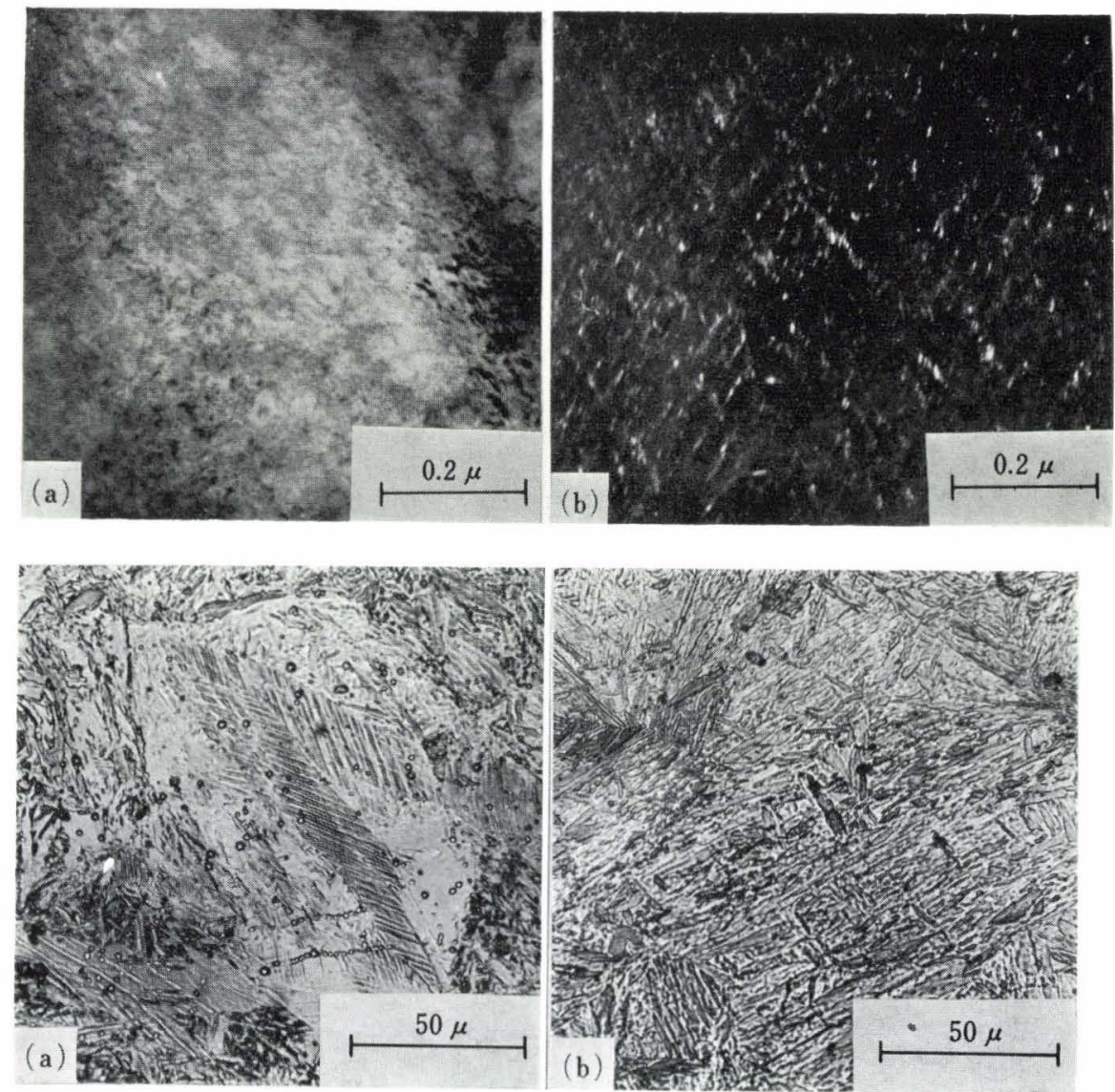

Photo. 4.

Transmission electron micrographs of the alloy $3\left(0.33 \% \mathrm{C}, \mathrm{Ms}: 350^{\circ} \mathrm{C}\right)$ as quenched state: (a) Bright field photograph, (b) Dark field photograph

Photo. 5.

Typical microstructures of the $0.33 \% \mathrm{C}$ alloys compressed at room temperature: (a) Alloy $6\left(\mathrm{Ms}\right.$ : $\left.-25^{\circ} \mathrm{C}\right)$ reduced about $29 \%$, (b) Alloy $3\left(\mathrm{Ms}\right.$ : $350^{\circ} \mathrm{C}$ ) reduced about $20 \%$ 
strength level of $200 \mathrm{~kg} / \mathrm{mm}^{2}$. Selecting an alloy in the martensites with $\mathrm{Ms}$ of $-25^{\circ} \mathrm{C}$, which has a same level of elongation about $14.5 \%$, the alloy (alloy 6) shows approximately $170 \mathrm{~kg} / \mathrm{mm}^{2}$ in strength, while at the level of $170 \mathrm{~kg} / \mathrm{mm}^{2}$ the martensite with $\mathrm{Ms}$ of $350^{\circ} \mathrm{C}$ (alloy 2) shows greater elongation than the martensite with $\mathrm{Ms}$ of $-25^{\circ} \mathrm{C}$ (alloy 6), as shown in Fig. 8. As a result, it was shown that in high strength levels such as above $160 \mathrm{~kg} / \mathrm{mm}^{2}$, the strength of martensites with $\mathrm{Ms}$ of $350^{\circ} \mathrm{C}$ was much higher than that of the martensites with $\mathrm{Ms}$ of $-25^{\circ} \mathrm{C}$ at similar elongation levels, and at the similar strength levels the elongation of the former was greater than that of the latter.

The mechanical properties of the $0.33 \% \mathrm{C}$ alloy with $\mathrm{Ms}$ of $350^{\circ} \mathrm{C}$ (alloy 3) when tempered at $140^{\circ}$ and $160^{\circ} \mathrm{C}$ are tabulated in Table 3 . In the asquenched condition, the elongation and reduction of area were relatively small but premature failure did not occur. On tempering, the elongation, reduction of area, and impact toughness began to improve from $120^{\circ} \mathrm{C}$ with a slight decrease in strength. According to the data accumulated for commercial high strength steels, ${ }^{13)}$ at strength levels between 140 and 175 $\mathrm{kg} / \mathrm{mm}^{2}$, steels show about $12 \%$ in elongation and $43 \%$ in reduction of area. As shown in Table 3, the tensile properties of the alloy 3 with $\mathrm{Ms}$ of $350^{\circ} \mathrm{C}$ when tempered at $140^{\circ}$ and $160^{\circ} \mathrm{C}$ are much superior compared to those of the commercial high strength steels. The impact energy versus test temperature of the alloy 3 are shown in Fig. 9. Tempering at $140^{\circ}$ and $160^{\circ} \mathrm{C}$ lowers the transition temperature, and also improves the toughness at subzero-temperatures above $-70^{\circ} \mathrm{C}$

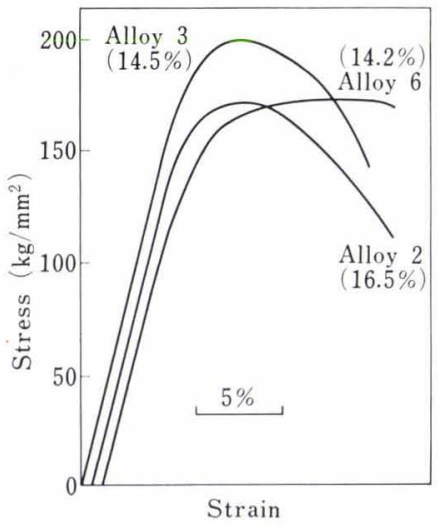

Fig. 8. Some typical stress-strain curves of the alloys 2, 3, and 6 tempered at $140^{\circ} \mathrm{C}$ respectively. Numerical value in percent shows total elongation.

Table 3. Mechanical properties of the alloy $3(0.33 \% \mathrm{C}$, Ms : $350^{\circ} \mathrm{C}$ ) temperd at $140^{\circ}$ and $160^{\circ} \mathrm{C}$

\begin{tabular}{c|c|c|c|c|c}
\hline $\begin{array}{c}\text { Temper- } \\
\text { ing } \\
\text { temp. } \\
\left({ }^{\circ} \mathrm{C}\right)\end{array}$ & $\begin{array}{c}\text { UTS } \\
\left(\mathrm{kg} / \mathrm{mm}^{2}\right)\end{array}$ & $\begin{array}{c}\text { YS } \\
\left(\mathrm{kg} / \mathrm{mm}^{2}\right)\end{array}$ & $\begin{array}{c}\text { Elonga- } \\
\text { tion } \\
(\%)\end{array}$ & $\begin{array}{c}\text { Reduction } \\
\text { of area } \\
(\%)\end{array}$ & $\begin{array}{c}\text { Impact } \\
\text { energy } \\
\text { a } 25^{\circ} \mathrm{C} \\
(\mathrm{kg}-\mathrm{m})\end{array}$ \\
\hline $\begin{array}{c}\text { As- } \\
\text { quenched }\end{array}$ & 217 & 175 & 2.6 & 6.0 & 2.3 \\
\hline 140 & 198 & 162 & 14.5 & 54.0 & 4.0 \\
\hline 160 & 188 & 154 & 16.0 & 60.0 & 4.5 \\
\hline
\end{tabular}

as well as at room temperature.

In summary, $\mathrm{Fe}-\mathrm{Ni}-\mathrm{C}$ martensites with $\mathrm{Ms}$ of $350^{\circ} \mathrm{C}$ revealed a much better combination of high strength and ductility than the martensites with Ms of $-25^{\circ} \mathrm{C}$. This suggests that precipitation during quenching gives an effective reason in increasing the strength and toughness of the martensite than artificial aging after quenching. Accordingly, it may be expected that an appropriate combination of Ms temperature and carbon content produces excellent mechancial properties in ferrous martensite.

\section{Conclusions}

The results obtained in this study are summarized as follows:

(1) Yield and ultimate tensile strengths of the martensite-austenite mixtures decreased linearly with increasing austenite content, and they ran parallel to each other.

(2) At a fixed strength level, in the as-quenched condition, the impact toughness of martensite with Ms of $350^{\circ} \mathrm{C}$ was superior compared to that of the martensite with $\mathrm{Ms}$ of $-25^{\circ} \mathrm{C}$.

(3) For tempered martensitic structures, at the same strength level, martensites with $\mathrm{Ms}$ of $350^{\circ} \mathrm{C}$ also showed better toughness than the martensites with $\mathrm{Ms}$ of $-25^{\circ} \mathrm{C}$ at the same level of carbon content.

(4) Martensites with $\mathrm{Ms}$ of $350^{\circ} \mathrm{C}$ showed a much better combination of high strength and ductility than the martensites with $\mathrm{Ms}$ of $-25^{\circ} \mathrm{C}$. As an example, it may be noted that the $0.33 \% \mathrm{C}$ alloy with $\mathrm{Ms}$ of $350^{\circ} \mathrm{C}$ has a value of $14 \%$ in elongation at strength level of $200 \mathrm{~kg} / \mathrm{mm}^{2}$ when tempered at $140^{\circ} \mathrm{C}$.

(5) It was observed that the preferable combination of high strength and good toughness in the alloys subjected to higher level of $\mathrm{Ms}$ temperature, $350^{\circ} \mathrm{C}$, may be attributed to the fine and uniform carbide distribution, dislocation substructure (lath martensite), deformation by slip, and absence of retained austenite. Accordingly, it may be concluded that an appropriate combination of $\mathrm{Ms}$ temperature and carbon content would produce excellent mechanical properties in ferrous martensites.

\section{Acknowledgements}

The authors express their thanks to Prof. S. Nagakura, Associate Profs. T. Suzuki and S. Nunomura, Mr. K. Hirotsu, Mr. J. Yamamoto, and Mr. G. Koba-

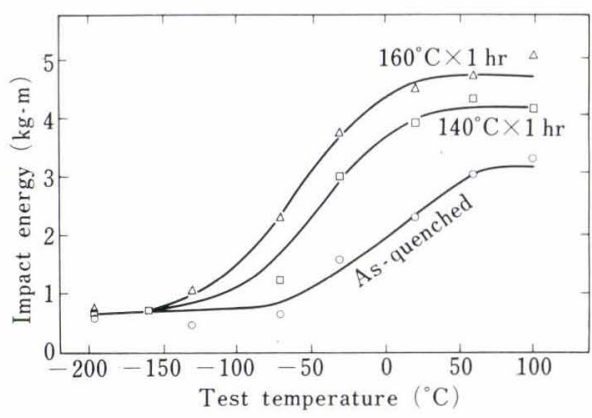

Fig. 9. Effect of tempering temperature on the impact test transition temperature curves for the alloy 3 $\left(0.33 \% \mathrm{C}, \mathrm{Ms}: 350^{\circ} \mathrm{C}\right)$ 
yashi of Tokyo Institute of Technology for their discussions and assistances in the experiments. The authors express also their hearty thanks to Prof. T. Araki, the University of Tokyo, Prof. I. Tamura, Kyoto University, and Prof. H. Sudo, Tohoku University for their kind suggestions and encouragements in this study.

\section{REFERENCES}

1) P. G. Winchell and M. Cohen: Trans. ASM, 55 (1962), 347.

2) M. J. Roberts and W. S. Owen: JISI, 206 (1968), 385.

3) J. Chilton and P. M. Kelly: Acta Met., 16 (1968), 637.

4) A. J. McEvily, R. C. Ku, and T. L. Johnston: Trans. Met.
Soc. AIME, 236 (1966), 108.

5) M. Tanaka and C. S. Choi: Trans. ISIJ, 12 (1972), 16.

6) R. H. Richman: Trans. Met. Soc. AIME, 227 (1963), 159.

7) I. Tamura and T. Ohyama: J. Japan Inst. Metal, 30 (1966), 1081.

8) C. L. Magee and R. G. Davies: Acta Met., 19 (1971), 345.

9) W. C. Leslie and R. J. Sober: Trans. ASM, 60 (1967), 459.

10) M. Tanaka and S. Nunomura: Bull. of Tokyo Inst. Technol., (1964), No. 60, 13.

11) M. Tanaka and C. S. Choi: Trans. ISIJ, 12 (1972), 298.

12) Y. H. Liu: Trans. ASM, 62 (1969), 55.

13) M. Tanaka and J. Yamamoto: Toward Improved Ductility and Toughness, (1971), 188, Symposium sponsored by AMAX. 